\title{
Methionine Aminopeptidase 2 Inhibitor M8891
}

National Cancer Institute

\section{Source}

National Cancer Institute. Methionine Aminopeptidase 2 Inhibitor M8891. NCI Thesaurus. Code C142831.

A proprietary orally available inhibitor of methionine aminopeptidase 2 (MetAP2), which cleaves the amino-terminal methionine residue from nascent proteins, with potential antiangiogenic and antineoplastic activities. Upon administration, MetAP2 inhibitor M8891 inhibits MetAP2 aminopeptidase activity and impairs protein synthesis, which may lead to a decrease in endothelial cell proliferation. Decreased proliferation of endothelial cells results in reductions of both angiogenesis and the growth and spread of solid tumors that are dependent on new blood vessel formation. MetAP2, a metallopeptidase, is involved in promoting protein synthesis and endothelial cell proliferation. 